Magdalena Bogusławska University of Warsaw

m.boguslawska@uw.edu.pl

ORCID: 0000-0002-8900-0458
Data przesłania tekstu do redakcji: 29.10.2019

Data przyjęcia tekstu do druku: 11.01.2020

\title{
Wędrująca idea awangardy. Centrum Dekontaminacji Kulturowej i serbska kultura oporu*
}

\begin{abstract}
Bogusławska Magdalena, Wędrujaca idea awangardy. Centrum Dekontaminacji Kulturowej i serbska kultura oporu (Wandering Idea of the Avant-garde. Centre for Cultural Decontamination and Serbian Resistance Culture). "Poznańskie Studia Slawistyczne" 18. Poznań 2020. Publishing House of the Poznań Society for the Advancement of the Arts and Sciences, Adam Mickiewicz University, pp. 23-36. ISSN 2084-3011.
\end{abstract}

The article addresses the presence of the avant-garde in the discourse and the practice of social resistance in Serbia at the turn of the $20^{\text {th }}$ and $21^{\text {st }}$ centuries. The focal point of the text is the thesis that nowadays the avant-garde resonates not so much as an artistic formation, but as an ideological complex. The author investigates the manners of contemporary transposition of ideas and avant-garde imagination through the analysis of the activities of the Centre for Cultural Decontamination in Belgrade. Using the examples of two programmes: Modernism, Serbian National Identity in $20^{\text {th }}$ Century and En Garde - Avant-Garde 20/21, the author shows how the local experience of the interwar avant-garde and the neo-avant-garde formed within the movement of ' 68 protests, creates a specific ideological current, a model of self-organization and a pattern of activities bordering between art and socio-political reality. In the 1990s, in Serbia, it becomes the reference system for artivism (an approach consisting in influencing social and political reality through art), and today still remains an inspiration for independent intellectual and artistic environments and for critical institutions that create an alternative and polemic cultural space to the official policies of the Serbian authorities.

KEYwords: wandering idea; artivism; resistance culture; Serbia; Centre for Cultural Decontamination

\section{Wędrująca idea - idea w działaniu}

Przeszczepiona przed stu laty na grunt sztuki kategoria awangardy - niczym bujna rafa koralowa - zdołała pomieścić w sobie ogromny

* Tekst został opracowany na podstawie badań przeprowadzonych w Serbii we wrześniu 2018 roku w ramach stypendium przyznanego przez Narodową Agencję Wymiany Akademickiej na podstawie umowy nr PPN/BIL/2018/1/74/SRB/UMOWA/1. 
i heterogeniczny zbiór zjawisk, nurtów, koncepcji artystycznych, dynamicznie sprzężonych z historią, rzeczywistością społeczną i polityką, pozostających ze sobą w relacji ciągłego przepływu i wzajemnego oddziaływania w mniej lub bardziej złożonych układach synchronicznych i diachronicznych. Z dzisiejszej perspektywy klasycznie pojmowana estetyczna waloryzacja fenomenu sygnowanego mianem awangardy (oraz neoawangardy), w moim przekonaniu, ma drugorzędne znaczenie wobec kulturotwórczego potencjału tej formacji ujawniającego się nie tylko w wymiarze historycznym, lecz również widocznego w odniesieniu do wyzwań współczesności. $\mathrm{O}$ ile historyczne wcielenia awangardy są odczytywane jako symptomy kolejnych etapów modernizacji, jako impuls cywilizacyjnej zmiany, o tyle jej aktualne, ponowoczesne zastosowania wymagają gruntownego przemyślenia programowania trybów rozumienia tego zjawiska. Według diagnozy Zygmunta Baumana pojęcie awangardy skazane jest dziś na porażkę, ponieważ okazuje się bezużyteczne w świecie pozbawionym stałych punktów i jasno zdefiniowanych porządków, do których mogłaby się ona krytycznie odnieść, które mogłaby przekroczyć i zakwestionować. W związku z tym, w warunkach zaniku historii na rzecz synchronii, sukcesji na rzecz współobecności, ma rację bytu wyłącznie jako - jedna z wielu - postawa estetyczna, styl, nostalgia czy ewentualnie ,ogołocona z dawnego sensu” metafora (Bauman, 1994, 176). A jednak - niejako wbrew pesymistycznym konstatacjom socjologa - awangarda, uosabiająca i uwalniająca transgresyjną moc twórczego myślenia i działania, nie przestaje być kategorią żywą i funkcjonalną, pozwalającą dziś zarówno zagospodarować pole sztuki (praktyki i refleksji), jak też wpływać i przekształcać rzeczywistość społeczną.

Jeśli zatem punktem wyjścia analizy uczynić nie generalizujące diagnozy mechanizmów rządzących ponowoczesną kulturą, a poszczególne koncepcje, partykularne doświadczenia, praktyki i wypowiedzi, jeśli spojrzeć nie z perspektywy globalności, z pozycji wiodących centrów, a przez pryzmat peryferii, okazuje się, że nadal istnieją obszary i sytuacje, w których awangarda zachowuje swą znaczeniową i aksjologiczną nośność. Bywa egzystencjalnym wyborem odciskającym własny ślad w konkretnych ludzkich biografiach. Utrzymuje swą moc przede wszystkim jako kompleks ideowy inspirujący krytyczne myślenie oraz zrodzone zeń projekty artystyczne i/lub społeczne. Objawia się jako idea wędrująca, czyli taka, która podlega kulturowej transmisji, posiada swą czasoprzestrzenną 
trajektorię, a jej logikę należy obserwować w dynamicznych ujęciach, pod kątem relacji warunkujących sposoby interpretacji jej semantyki, a także kierunki i strategie (adaptacyjnych) przekształceń.

Na gruncie badań slawistycznych, czego dowodzi chociażby lektura opublikowanych dotychczas tomów Leksykonu idei wędrownych na słowiańskich Bałkanach, poręczny, a zarazem oczywisty układ odniesienia dla namysłu nad transferem uniwersaliów kulturowych - idei, kategorii, pojęć - stanowią narodowe uniwersa (Szwat-Gyłybowa, 2018). To one tworzą ramę znaczeniową, społeczną i komunikacyjną dla określonych wykładni idei. Wytwarzają struktury adaptacyjne, wyznaczają kierunki transferu, wpływają na tryby aktualizacji oraz sposoby artykulacji treści przez te idee konotowanych. $\mathrm{Z}$ kolei idee stają się podstawowym narzędziem porządkowania zbiorowych imaginariów, stanowią podłoże zasad koordynujących społeczne działania, postawy, myślenie i podobnie jak one podlegają procesom instytucjonalizacji w ramach organizacyjnych struktur wspólnoty, jakie ustanawia na przykład państwo. Podążając za rozważaniami Grażyny Szwat-Gyłybowej, należy także dodać, że praca wędrujących (wędrownych) idei ulega intensyfikacji w sytuacji kryzysu, w warunkach entropii, kiedy to społeczeństwa poszukują odpowiednich koordynatów dla zdefiniowania własnej tożsamości oraz pozycji. W związku z czym podejmują wysiłek uformowania adekwatnego języka, który wspomógłby rozumienie i nazwanie własnego, trudnego doświadczenia, a jednocześnie który by nie naruszył poczucia wewnątrzsterowności (Szwat-Gyłybowa, 2018, 9). Wszakże terytorium symboliczne danej kultury można scalić, ale także zintegrować z konglomeratem zewnętrznych imaginariów jedynie poprzez wędrówkę, poprzez ruch myśli.

Interesującym przykładem naszkicowanego powyżej mechanizmu jest funkcjonowanie idei awangardy, która stale odradza się i aktywizuje swą semantykę w coraz to nowych modalnościach i kontekstach. Pozostaje ona w ciągłym ruchu, działa w różnych rejestrach wyobraźni oraz aktywności społecznej, wchodzi w alianse z rozmaitymi systemami filozoficznymi i światopoglądowymi. Co więcej, podlegając ciągłej aktualizacji w znaczących układach problemowych współczesności, obserwowanych zarówno w wymiarze uniwersalnym, jak i lokalnym, zwiększa swą ideologiczną i polityczną produktywność. Dynamikę jej kulturowego transferu potęguje fakt, iż z definicji swej awangarda balansuje pomiędzy tym, co uniwersalne i idiomatyczne, transnarodowe i partykularne. Dobrym przykładem tak 
pojmowanej pracy idei awangardy jest jej współczesna recepcja w Serbii, którą chciałabym omówić na podstawie działalności belgradzkiego Centrum Dekontaminacji Kulturowej będącego jednym z filarów serbskiej kultury oporu na przełomie XX i XXI wieku.

\section{Od nadrealizmu do artywizmu}

Przyczyną reaktualizacji doświadczeń awangardy z okresu pierwszej i neoawangardy z czasów drugiej Jugosławii, a także motywacją dla zrewitalizowania i „przeramowania” (reframing; Bal, 1999) ideowych założeń obu formacji intelektualno-artystycznych w latach dziewięćdziesiątych XX wieku stał się przypieczętowany bratobójczą wojną rozpad socjalistycznej Federacji oraz budowana na nacjonalizmie polityka konfliktu. $\mathrm{Na}$ tym tle odniesienie niezależnych środowisk artystycznych oraz intelektualnych do tradycji awangardy oznaczało nie reaktywację czy też naśladownictwo faktów estetycznych, dzieł czy historycznych poetyk, lecz przefiltrowane przez paradygmaty nowoczesnego rozumienia świata i współczesną wyobraźnię - odwołanie do jej etosu. Awangardowy impuls ex definitione zakłada przesunięcie akcentów z poziomu teoretyzowania, tekstu, planu, w sferę praktyki i $\mathrm{z}$ tego względu stanowi obietnicę realnej zmiany. W Serbii lat dziewięćdziesiątych myślenie awangardą musiało stać się domeną działania. Tu i teraz. Wobec rozpadu instytucjonalnych podstaw jugosłowiańskiej przestrzeni symbolicznej i zastąpienia ich elitami konstruowanymi naprędce, $\mathrm{w}$ atmosferze nacjonalistycznej mobilizacji kluczową sprawą była afirmacja nieformalnych sposobów działania i organizacji alternatywnych wobec sił reżimu kolonizującego społeczną tożsamość, umysły i postawy. Siłą, która wprawiła w ruch serbską kulturę oporu stały się środowiska uformowane między innymi w łonie neolewicowej rewolty ' 68 , w toku protestów studenckich, związane z ruchem jugosłowiańskiej neoawangardy lat siedemdziesiątych, a także z filozoficznymi kręgami czasopisma „Praxis”. Przedstawiciele tego kręgu, Nebojša

${ }^{1} \mathrm{O}$ filozofii sprzeciwu kształtowanej na łamach czasopisma „Praxis”, która stała się inspiracją dla serbskiej kultury oporu w latach dziewięćdziesiątych, pisze obszernie Božidar Jakšić w monografii Praxis - mišljenje kao diverzija (Jakšić, 2012). 
Popov, Latinka Perović, Radomir Konstantinović, Ivan Čolović i wielu innych, którzy w obliczu pogłębiającego się kryzysu inicjowali powstanie pokojowych i antywojennych organizacji, takich jak pismo „obywatelskiego samowyzwolenia” „Republika” (1989), Žene u crnom (1991), Centar za antiratnu akciju (1991), Beogradski krug (1992), których aktywność miała dowodzić możliwości ukonstytuowania niezależnych nurtów demokratycznego, obywatelskiego społeczeństwa oddolnie, wbrew wojnie i narzuconej wersji patriotyzmu. To właśnie te przesłanki stały się budulcem koncepcji „Innej Serbii” (serb. Druga Srbija, ang. Other Serbia) i sprzężonej z nią ,alternatywnej sceny” kulturalnej (Šušak, 1996, 531)². Niezależne stowarzyszenia, podobnie jak dawniej grupy awangardowe, tworzyły rodzaj dynamicznej konfiguracji istniejącej dzięki współpracy konkretnych ludzi i przepływowi idei. Wykorzystywano różnorodne metody działania: od aktywności na rzecz politycznych ugrupowań opozycyjnych, poprzez demonstracje, debaty, publikacje, po akcje miejskie i spektakle teatralne; za to cel był wspólny - polityczny.

Kojarzone z awangardą: akcjonizm, procesualność, zdarzeniowość, transgresyjność, uniwersalizm, stanowiły alternatywę dla heroizacji, mitologizacji, upomnikowienia i monumentalizacji przeszłości odczytywanej w kluczu narodowego partykularyzmu i ekskluzywizmu. Awangarda, której wykładnia pozostaje zakorzeniona w myśleniu progresywnym oraz w idei nowoczesności rozumianej jako projekt (auto)krytyczny (Boym, 2015, 193), pozwalała osadzić protest w szerszym, ponadlokalnym układzie sensów, a tym samym przełamać narodocentryczną perspektywę i utworzyć przeciwwagę dla retradycjonalizacji kultury, która wyznaczyła kierunek serbskiej polityki w końcu XX wieku. W zabiegu tym, szczegółowo analizowanym przez wielu badaczy, takich jak Slobodan Naumović, Dubravka Stojanović, Olga Manoilović Pintar, Ivan Čolović, Todor Kuljić, można rozpoznać charakterystyczną dla transformacji systemowej strategię powrotu - przypomnienia tego, co w świadomości zbiorowej

${ }^{2}$ Obszerny przegląd przedsięwzięć związanych z ruchem Innej Serbii prezentuje Bojana Šušak w tomie Srpska strana rata pod redakcją Nebojšy Popova (Šušak, 1996), z kolei sposoby działania i tradycje niezależnych organizacji w Serbii analizuje Dragan Stojković w artykule Antiratne $i$ mirovne ideje $u$ istoriji Srbije $i$ antiratni pokreti do 2000. godine (Stojković, 2011). Bilans serbskiej kultury protestu sporządza także Milena Dragićević Šešić w swej najnowszej monografii Kultura i umetnost otpora (Dragićević Šešić, 2018). 
stłumione. W interesującym nas przypadku retradycjonalizacja oznacza zatem po pierwsze odzyskanie i uruchomienie na nowo treści historycznych dotychczas uznawanych za zagrożenie dla integralności podmiotowości jugosłowiańskiej; po drugie zaś prowadzi do zakwestionowania komunistycznego/socjalistycznego modelu modernizacji w przekonaniu, że stanowiła ona w przeszłości narzędzie upodrzędnienia i kolonizacji serbskiego etnosu. Stąd afirmacja średniowiecznych i dziewiętnastowiecznych tradycji państwowych sprzężonych z kultem narodowego prawosławia (Naumović, 2009), instrumentalizacja folkloru, a także popularność tezy, że główną rolę inicjującą i stymulującą nowoczesny rozwój Serbii odegrała nie klasa mieszczańska, a rdzenna ludność wiejska, która dzięki samoorganizacji i charyzmatycznemu przywództwu, w toku powstań narodowych w XIX wieku zapewniła państwu suwerenność i wyznaczyła wewnętrzny puls jego funkcjonowania (Naumović, 2009, 92). Ta ostentacyjnie retroaktywna orientacja potwierdza diagnozę Borisa Groysa, który konstatuje, że ,życie postkomunistyczne to życie przeżywane wstecz, to ruch wbrew nurtowi czasu" (Groys, 2015, 164). Logika owego ruchu ku przeszłości w sytuacji kryzysu i rozpadu dotychczasowych struktur identyfikacji polega na dążeniu do zdefiniowania i artykulacji wspólnej tożsamości, a także ustanowienia jej continuum w nowych warunkach politycznych, ekonomicznych, cywilizacyjnych. A zatem wywrotowość myślenia i działania w twórczo interpretowanych kategoriach awangardy polegała na demaskowaniu przekonania o autentyczności, autochtoniczności i wewnątrzsterowności tych działań jako przejawu prowincjonalizmu, jako iluzji odzyskanej suwerenności rozgrywanej w imię politycznej mobilizacji obywateli.

Na przełomie 1993 i 1994 roku na belgradzkiej mapie kultury protestu pojawiło się Centrum Dekontaminacji Kulturowej (Centar za kulturnu dekontaminaciju) założone przez dramaturżkę, animatorkę kultury i felietonistkę Borkę Pavićević oraz reżyserkę i antropolożkę Anę Miljanić. Od początku istnienia instytucja sytuowała się w nurcie, który Aldo Milohnić nazywa artywizmem (Milohnić, 2013, 78), rozumiejąc pod tym powstałym ze złożenia ze słów art (sztuka) i aktywizm pojęciem aktywność wykorzystującą sztukę w funkcji medium akcji politycznej, jako oręż kontestacji. Byłby więc artywizm takim działaniem w sztuce i poprzez sztukę, które odrzuca bezpieczną, a zarazem podejrzaną moralnie zasadę autonomii 
sztuki, opiera się na zaangażowaniu ideowym i etycznym, które zmierza do afirmacji określonych wartości i którego sens stanowi twórcze oddziaływanie i przekształcanie tego, co wobec sztuki zewnętrzne. Postawa ta stawia w centrum międzyludzkie relacje, nie godzi się z defetyzmem, pasywizmem, uległością i obojętnością. Wzorem awangardy i neoawangardy, będąc wyrazem performatywnej, a zarazem politycznej wrażliwości estetycznej, sytuuje się - jak konstatuje Milohnić $(2013,78)$ - w kontrze do mimetycznej estetyki i ideologii mieszczańskiej. W Serbii ostatniej dekady $\mathrm{XX}$ wieku to właśnie w kulturze dostrzegano najefektywniejszy czynnik zmiany społecznej (Dragićević Šešić, 2018, 145). Ostrze artywizmu zostało wymierzone w anachroniczny epicki patos, militarystyczny i/lub pseudoreligijny kicz patriotyczny, estradowy banał i propagandową tandetę, które w epoce Miloševicia uznawano za wyznaczniki smaku, za pryncypia organizujące serbskie - narodowe doświadczenie estetyczne.

Dla Centrum Dekontaminacji Kulturowej sztuka, zwłaszcza teatr i performans, stanowią naturalną formę interwencji w sferę polityki i warunkowaną przez nią czasoprzestrzeń codziennego życia, w międzyludzkie relacje. Nic zatem dziwnego, że to właśnie awangarda radykalnie przewartościowująca status sztuki jako praktyki społecznej (Foster, 2012, 29) stała się w programie Centrum kluczowym punktem odniesienia. Nawiązanie do awangardy silnie wybrzmiało w projekcie Moderna, srpski nacionalni identitet $u X X$ veku realizowanym w 2001 roku. Objął on między innymi przypomnienie opublikowanego w 1919 roku w wydawanym w Zagrzebiu pod redakcją Miroslava Krležy czasopiśmie „Plamen” (nr 5-6) wystąpienia pt. Manifest jugoslavenskih progresivnih intelektualaca, spektakl Bordel ratnika wyreżyserowany przez Anę Miljanić na podstawie tekstów Ivana Čolovicia oraz debatę Antifašizam - moderna - srpsko nacionalno pitanje u 20. veku ${ }^{3}$. Zgodnie z założeniami twórców celem przedsięwzięcia były: dekonstrukcja i przeprogramowanie myślenia o serbskiej współczesności, zawieszenie czy też „rozbrojenie” forsowanych przez autorytarne władze dominant zbiorowej autorefleksji, takich

${ }^{3}$ W debacie, która odbyła się 15 września 2001 roku w Muzeum „25 Maja” (Muzeum Jugosławii) w Belgradzie, obok organizatorek: dyrektorki Centrum Dekontaminacji Kulturowej Borki Pavićević i historyczki Branki Prpy, uczestniczyli w roli prelegentów: historyczka Latinka Perović, socjolog Todor Kuljić, pisarz Filip David, reżyserka Mira Erceg i profesor prawa Jovica Trkulja. 
jak zmitologizowane kategorie narodu, nacji, tożsamości narodowej, etnosu itp., na rzecz autorefleksji zogniskowanej wokół sproblematyzowanych i krytycznie ujmowanych wartości modernizacji i emancypacji. W rozmowie z Joanną Wichrowską Borka Pavićević tłumaczyła przesłanie inicjatywy Centrum, wymieniając wśród różnych, przynależnych do rodzimej kultury zakotwiczeń symbolicznych, także nadrealizm uznawany za wiodący nurt serbskiej awangardy:

Grupa badaczy, naukowców, artystów przypominała młodym ludziom, że cerkiewna, epicka, narodowa kultura to nie jedyna tradycja Serbii. Że oprócz niej istniał też serbski surrealizm, albo czasopismo „Srpski književni glasnik”, w którym zamieszczano teksty we wszystkich możliwych jugosłowiańskich językach i nikomu nie przyszło do głowy je thumaczyć. Że Serbia ma tradycje abstrakcyjnego myślenia, filozofii i refleksji politycznej, dla której głównym punktem odniesienia nie jest naród. Że na początku XX wieku serbskie kobiety studiowały w Wiedniu i nikt im nie mówil, że rodzime uniwersytety są najlepsze w świecie. Chcieliśmy odświeżyć modernistyczne wzorce, które zostały zepchnięte na dalszy plan przez inną narrację, pielęgnującą mity narodowe i podkreślającą znaczenie Cerkwi w kształtowaniu tożsamości narodu (Pavićević, 2012).

Celem projektu Moderna było rozpoznanie na gruncie serbskim oraz szerzej - jugosłowiańskim tradycji legitymizujących instytucjonalne działania oraz wyznaczających horyzont ideowy nurtu demokratyczno-liberalnego, a zwłaszcza promowanej przezeń pozytywnej, włączającej wizji życia społecznego i kultury w szczególnej sytuacji historycznej, jaką stała się tzw. rewolucja 2000 roku, w wyniku której Slobodan Milošević został odsunięty od władzy i postawiony przed Międzynarodowym Trybunałem Karnym w Hadze. Ocena reżimu i nadzieja na gruntowną zmianę wiązała się z koniecznością podjęcia przez krąg współpracowników Centrum Dekontaminacji Kulturowej nowych zadań, które zmierzałyby do wydobycia serbskiej kultury z izolacji, w jaką - przy aprobacie większości społeczeństwa - wtłoczyła ją etnokratyczna polityka reżimu. Potrzeba wzięcia odpowiedzialności za transformację (Ivan Čolović [2002] nazywa tego rodzaju postawę etyką odpowiedzialności) to również punkt wspólny między optyką belgradzkiego Centrum i myśleniem awangardowym - wszakże mierzenie się z ryzykiem to domena awangardy.

Ważne było to, by spojrzeć na rozgrywające się w kraju wydarzenia, przekraczając lokalną skalę, studząc gorączkę polityczną, a także by nie 
poprzestawać na formułowaniu doraźnych sensów. Stąd też ramą interpretacyjną projektu Moderna uczyniono toczącą się nieprzerwanie od lat dziewięćdziesiątych dyskusję na temat zagrożenia faszyzmem w Europie po upadku żelaznej kurtyny oraz tego, jak w tendencję do refaszyzacji świadomości i pamięci społecznej (postrzeganej jako remedium na komunizm) wpisuje się - jak mówi Latinka Perović - „naš, domaći fašizam” (rodzimy faszyzm, faszyzm „domowej roboty”) (Miljanić, 2001, 3-4). Podczas okrągłego stołu poświęconego temu problemowi pytano o potencjał antyfaszyzmu jako określonego systemu aksjologicznego, o dostępne formy aktualizacji jego przekazu w sytuacji rozpadu instytucji i degradacji norm etycznych, a jednocześnie wskazywano na aporie (wynikające choćby z odmienności doświadczeń narodów europejskich), które utrudniają stworzenie uwspólnionej platformy znaczeń mogącej stanowić punkt wyjścia dla konsensu w ocenie historycznych inkarnacji totalitaryzmów - faszyzmu i komunizmu.

Ta perspektywa wydobywa określone aspekty i znaczenia przywołanego przez Borkę Pavićević nadrealizmu. Będący efektem głębokich związków serbskiej sceny artystycznej z ośrodkami francuskiej awangardy po pierwszej wojnie światowej, utrzymał silną pozycję w połowie XX wieku w ideowym dyskursie jugosłowiańskim, a także serbskim, nie tyle dzięki dokonaniom artystycznym, eksperymentom i koncepcjom z zakresu poetyki czy estetyki, ile za sprawą politycznej orientacji związanych z nim twórców zaangażowanych w komunizm, kwestie klasowe i jugosłowiańską rewolucję. Stąd też historyczny nadrealizm w wokabularzu serbskiej „alternatywy” liberalno-demokratycznej staje się synonimem antyfaszyzmu, a takie postaci, jak Konstantin Koča Popović - filozof, który w 1931 roku we współpracy z Markiem Risticiem ogłosił manifest belgradzkich surrealistów opublikowany pod tytułem Nacrt za jednu fenomenologiju iracionalnog, uczestnik wojny domowej w Hiszpanii, charyzmatyczny dowódca partyzancki, po drugiej wojnie światowej polityk i dyplomata, a w czasach rządów Slobodana Miloševicia dysydent - są postrzegane w roli patronów postulowanej „defaszyzacji” kultury i zbiorowej świadomości. Zagadnieniem wymagającym osobnych rozważań pozostaje kwestia, na ile serbski nadrealizm jako nurt artystyczno-intelektualny był przejawem rzeczywistej modernizacji społeczeństwa w okresie międzywojnia, a na ile próby zaimplementowania go na wzór francuski 
w warunkach bałkańskich obnażały elitarność (czytaj: niezrozumiałość) i utopijność (by nie powiedzieć jałowość) zawartego w nim projektu społecznego i politycznego, napotykającego na barierę w postaci patriarchalnego świata palanki tak przenikliwie opisanego przez Radomira Konstantinovicia - zamkniętego, monologicznego i całkowicie przewidywalnego świata obyczajowej rutyny, infantylnego sentymentalizmu, plemienności wyniesionej do rangi normatywnego super ego (Konstantinović, 2004). Organizm palanki odrzuca implant awangardy (ucieleśnienie światowości, krytycyzmu, subwersji) w imię czystości oraz integralności stanowionego przez siebie porządku. W związku z tym, jak twierdzi Jovica Trkulja, parafrazując sformułowanie Ralfa Dahrendorfa, w przypadku dwudziestowiecznej Serbii mamy do czynienia z „modernizacją bez nowoczesności” (modernizacjia bez modernosti) (Miljanić, 2001, 7), a przecież to właśnie przeżycie i przepracowanie doświadczenia awangardy zdaje się być czynnikiem umożliwiającym domknięcie modernizacyjnego procesu.

\section{Awangarda jako lekcja pamięci}

Ewoluujący w stronę lewicowego humanizmu i tzw. sztuki socjalnej serbski nadrealizm był tą praktyką artystyczną, dla której estetyka i sztuka stanowiły pole działania nieświadomego, a postulowana przez przedstawicieli nurtu twórczość rewolucyjna miała uwolnić uwięzioną świadomość i wyobraźnię, w tym także stać się przestrzenią konfrontacji z ich ciemną, ukrytą stroną (Sretenović, 2016). Estetyka jest tu symptomem, ale jednocześnie wprzęgnięta w twórczą pracę może destabilizować zastany układ, a także być formą terapii. Tak zaprojektowany eksperyment artystyczno-intelektualny staje się u progu XXI wieku dla Centrum Dekontaminacji Kulturowej lekcją ideowego i politycznego nonkonformizmu, a wolnościowa, emancypacyjna i krytyczna postawa rewolucyjnie zorientowanych artystów z okresu międzywojnia zostaje uznana za bliską myśleniu twórców i współpracowników ośrodka o sposobach opozycyjnego działania w przestrzeni publicznej poprzez sztukę. W przypadku programu Moder$n a$, a także w ramach innych przedsięwzięć Centrum - spektakli, wystaw, debat, warsztatów - domeną spotkania sztuki z tym, co społeczne, staje się przestrzeń zbiorowej pamięci. Moderna - konstatuje Milena Dragićević 
Šešić - staje się pasażem do „całkowicie nowej kultury pamięci” (Dragićević Šešić, 2018, 387). Chodzi głównie o demaskowanie i dekonstrukcję mechanizmów zbiorowego zapominania i przypominania, uruchamianych w celu generowania niebezpiecznych fikcji, którymi można łatwo uwodzić masy. Drugi krok to przywołanie wypartych pokładów przeszłości, bez konfrontacji z którymi nie sposób mówić czy to o społecznym katharsis, czy też właśnie o „kulturowej dekontaminacji”, a więc o oczyszczeniu serbskiej rzeczywistości z zatruwających ją i skazujących na erozję toksyn, tak by móc na nowo scalić sens. Wpływ awangardowego trybu postrzegania czasowości wyraża się w sposobie traktowania przez Centrum Dekontaminacji Kulturowej pamięci - ma ona wartość nie jako przedmiot apologii czy instrument władzy, ale jako wiedza będąca katalizatorem projektowania i przekształcenia przyszłości.

Ze względu na historyczno-polityczne konotacje nawiązania do awangardy okresu międzywojnia, a jeszcze silniej do neoawangardy z drugiej połowy XX wieku, wydają się obciążone dużym ryzykiem, ponieważ obie formacje są dziś bezpośrednio kojarzone z kulturą jugosłowiańską oraz internacjonalizmem pozostającym nieusuwalnym elementem jej doświadczenia (zwłaszcza w odsłonie z lat sześćdziesiątych i siedemdziesiątych). W związku z tym identyfikacja z problematyczną i niejednoznacznie ocenianą kartą przeszłości powoduje, że dziedzictwo historycznych awangard zostaje wyparte $\mathrm{z}$ dyskursów legitymizujących politykę renacjonalizacji i narodocentrycznie konstruowanych kanonów kultury (Dimitrijević, 2016, 7). Bywa również partykularyzowane w obawie przed możliwością uwspólnienia pamięci, które wydaje się zagrożeniem dla „odzyskanej”, kruchej podmiotowości krajów powstałych po rozpadzie SFRJ, manifestujących własną odrębność poprzez atrybut etnicznej swoistości i poprawności uzgodnionej z politycznym centrum. Tak zorientowany wybór zawsze niesie ze sobą określone konsekwencje etyczne. Prowadzi do ekskluzywizmu i zamknięcia, a także do zanegowania wartości uniwersalnych w imię - posłużmy się słowami Miška Šuvakovicia - hegemonii jednej prawdy, jednego narodu, jednej religii, rasy, płci, poetyki, jednego stylu (Шуваковић, 2006, 85). Dla belgradzkiego Centrum socjalistyczna Jugosławia - Jugosławia spod znaku neoawangardowej Trybuny Młodych z Nowego Sadu, teatralnego festiwalu BITEF, neolewicowego czasopisma „Praxis” oraz realizmu społecznego filmów Želimira Žilnika - to nie 
przedmiot nostalgii, materia estetycznych bądź ludycznych retrospektyw, ale jakość mieszcząca się w porządku osobistego doświadczenia twórców ośrodka, a przede wszystkim ideologiczna oś wyprowadzona z wnętrza wielogłosowej, heterogenicznej przestrzeni kulturalnej, która może funkcjonować dziś w dyskursie publicznym jako kontra dla polityki zerwania, rozpadu, wykluczenia.

Zorganizowany w 2014 roku przez Centrum Dekontaminacji Kulturowej i Fundację Heinricha Bölla we współpracy z Instytutem Goethego w Belgradzie oraz Stowarzyszeniem Krokodil program En Garde, Avant-Garde 20/21 - „Čovek peva posle rata” był kolejnym etapem namysłu nad znaczeniem awangard reaktualizowanych w warunkach ustanawiania nowych hierarchii i porządków dominacji jako wywrotowy, „emancypacyjny gest polityczny” (Dimitrijević, 2016, 46), jako impuls zmiany. Temat awangardy powrócił tym razem, w setną rocznicę wybuchu pierwszej wojny światowej, z silnym antywojennym przesłaniem podczas cyklu otwartych spotkań edukacyjnych (Avangarde, Dimitrije Tucović, Slike o ratu) i debat (Nekad i sad, Identitet po izboru), pokazów filmów oraz performansów (Šetnja za Dimitrija Tucovića Marka Brecelja, Izopšteni. U trenutku opasnosti grupy Chto Delat), a także prezentacji prac artystów wizualnych (dzieł plastycznych z 1914 roku i projektu Bad design Igora Bošnjaka) ${ }^{4}$. W owej potrzebie przemyślenia awangard - różnych sposobów ich reartykulacji (Dimitrijević, 2016, 17), semantycznych przemieszczeń samego pojęcia w warunkach transformacji systemowej, w rzeczywistości poddanej dyktatowi rynku, totalności konsumpcji oraz mechanizmom komercjalizacji - wyraża się szersza intencja pobudzenia zmysłu refleksyjności. Zaangażowanej, krytycznej, przekraczającej konwencje. W wypowiedzi inaugurującej program En Garde, Avant Garde Borka Pavićević wskazała wprost na doświadczenie awangardy jako zapomniany czy też intencjonalnie odsunięty poza nurt oficjalnych narracji tożsamościowych wzorzec

\footnotetext{
${ }^{4}$ Patronem cyklu organizatorzy uczynili Dimitrija Tucovicia - żyjącego na przełomie XIX i XX wieku działacza i teoretyka serbskiego ruchu socjalistycznego, zwolennika utworzenia federacji krajów bałkańskich, antymilitarysty, autora słynnej broszury Srbija i Albanija. Jedan prilog zavojevačke politike srpske buržoazije (1914), w której sprzeciwiał się wielkoserbskiej polityce Nikoli Pašicia i eksterminacji ludności albańskiej na Kosowie. W latach dziewięćdziesiątych serbskie władze uznały Tucovicia za zdrajcę, a jego dokonania i teksty poddano planowej polityce zapomnienia. Więcej na ten temat v. Samardžić, Bešlin, 2015.
} 
deprowincjonalizacji oraz europeizacji serbskiej kultury, punkt wyjścia dla krytycznego sposobu jej rozumienia oraz uczestniczenia w niej (Dimitrijević, 2016, 7). Rozpięta pomiędzy przeszłością a przyszłością trajektoria idei awangardy pozwala definiować pozycję środowiska skupionego wokół Centrum hasłem-metaforą En Garde!, co oznacza trwanie na straży, ciągłą gotowość, postawę oporu.

\section{Awangarda i etos oporu}

Działalność Centrum Dekontaminacji Kulturowej dostarcza licznych przykładów praktycznego zastosowania idei awangardy, a tym samym umożliwia odpowiedź na pytanie, dlaczego jest ona tak silnie obecna w obiegu serbskiej kultury niezależnej. Współczesna nośność awangardowej wyobraźni wynika z jej szczególnego statusu w humanistyce, z tego, że jest - co podkreśla Barbara Czapik-Lityńska - „nie tylko propozycją sztuki, ale i propozycją etosu, propozycją działania i życia" (Czapik-Lityńska, 1996, 143). W swych historycznych inkarnacjach awangarda stanowi dla artystycznych i intelektualnych praktyk oporu rezerwuar modeli niezawisłego myślenia, wzorców samoorganizacji, a także alternatywnych form budowania życia społecznego, politycznego i artystycznego. W świecie bezładnie wykonywanych ruchów i znoszących się wzajemnie sensów, w którym ,jedna zmiana miejsca nie różni się od drugiej” (Bauman, 1994, 171) pozwala zarówno jednostkom, jak i zbiorowościom wyznaczyć mimo wszystko określony porządek wartości i przywrócić utracone poczucie sprawczości.

\section{Literatura}

Bal, M. (1999). Quoting Caravaggio: Contemporary Art., Preposterous History. Chicago-London: University of Chicago Press.

Bauman, Z. (1994). Ponowoczesność, czyli o niemożliwości awangardy. „Teksty Drugie" nr 5/6 (29/30), s. 171-179.

Boym, S. (2015). Anioł historii. Nostalgia i nowoczesność. Przeł. K. Rychter. „Kronos” nr 3 (34): Budowa nowoczesności, s. 190-202. 
Čolović, I. (2002). Druga Srbija. „Pešćanik” 30.11.2002. https://pescanik.net/druga-srbija/, 1.09.2019.

Czapik-Lityńska, B. (1996). „Jeszcze nie”. Utopicum jugostowiańskiej awangardy. Katowice: Wydawnictwo Uniwersytetu Śląskiego.

Dragićević Šešić, M. (2018). Umetnost i kultura otpora. Beograd: Institut za pozorište, film, radio i televiziju Fakulteta dramskih umetnosti-Clio.

Dimitrijević, B. (ur.) (2016). En Garde 20/21. Beograd: Heinrich Böll Stiftung-Centar za kulturnu dekontaminaciju.

Foster, H. (2012). Powrót realnego. Awangarda u schyłku XX wieku. Przeł. M. Borowski, M. Sugiera. Kraków: Universitas.

Groys, B. (2015). Poza różnorodnością: kulturoznawstwo i jego postkomunistyczny inny. Przeł. R. Kuczyński. „Kronos” nr 3 (34): Budowa nowoczesności, s. 159-170.

Jakšić, B. (2012). Praxis - mišljenje kao diverzija. Beograd: Službeni glasnik.

Konstantinović, R. (2004). Filosofija palanke. Beograd: Otkrovenje.

Miljanić, A. (red.) (2001). Antifašizam. Okrugli sto, Muzej „,25 Maj”, 25.09.2001 [zapis debaty]. „Glasilo projekta «Moderna, srpski nacionalni identitet u XX veku»” br. 5 .

Milohnić, A. (2013). Koreografije otpora. „Teorija koja hoda. Impresum” br. 21: Društvena koreografija, s. 15-20.

Naumović, S. (2009). Upotreba tradicije u političkom i javnom životu Srbije na kraju dvadesetog i početkom dvadeset prvog veka. Beograd: Institut za filozofiju i društvenu teoriju-Filip Višnjić.

Pavićević, B. (2012). Magiczna ściereczka [wywiad przeprowadzony przez J. Wichowską]. http://www.dwutygodnik.com/artykul/3867-magiczna-sciereczka.html, nr 89. 1.09.2019.

Samardžić, M., Bešlin, M. (2015). Nova čitanja Dimitrija Tucovića 100 godina posle: zbornik radova. Novi Sad: Alternativna kulturna organizacija AKO.

Sretenović, D. (2016). Urnebesni kliker. Umetnost i politika beogradskog nadrealizma. Beograd: Službeni glasnik.

Stojković, D. (2011). Antiratne i mirovne ideje u istoriji Srbije i antiratni pokreti do 2000. godine. „Republika” br. 429-493. http://www.republika.co.rs/492-493/20. html. 1.09.2019.

Szwat-Gyłybowa, G. (2018). Kilka uwag o sile i bezsilności badaczy idei wędrownych. W: Leksykon idei wędrownych na stowiańskich Batkanach XVIII-XXI wiek, t. 1: Oświecenie - religia - racjonalizm. Warszawa: Instytut Slawistyki Polskiej Akademii Nauk, s. 7-16.

Šušak, B. (1996). Alternativa ratu. W: Srpska strana rata. Trauma i katarza u istorijskom pamćenju. Ur. N. Popov. Zrenjanin: Republika, s. 531-545.

Шуваковић, М. (2006). Фаренхајт 387. Теоријске исповести. Нови Сад: Орфеус. [Šuvaković, M. (2006). Farenhajt 387. Teorijske ispovesti. Novi Sad: Orfeus]. 